\title{
PRIVATE PARTICIPATION IN RULER CULTS: DEDICATIONS TO PHILIP SŌTĒR AND OTHER HELLENISTIC KINGS*
}

Hellenistic ruler cult has generated much scholarly interest and an enormous bibliography; ${ }^{1}$ yet, existing studies have tended to focus on the communal character of the phenomenon, whereas the role of private individuals (if any) in ruler worship has attracted little attention. This article seeks to redress this neglect. The starting

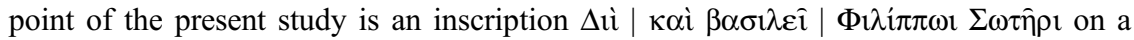
rectangular marble plaque from Maroneia in Thrace. ${ }^{2}$ Since the text was published in 1991, it has been disputed whether the king in question is Philip II or Philip V of Macedon. The question is further complicated by a newly published text from Thasos, plausibly restored to read [B] $\alpha \sigma \lambda \lambda \dot{\varepsilon} \omega \varsigma$ $\Phi \iota \lambda \hat{i}[\pi \pi \mathrm{ov}] \mid \sigma \omega \tau \hat{\eta} \rho \varsigma_{\zeta}{ }^{3}$ The identity of the king in these texts is a matter of great historical significance: if Philip II is meant, not only would this impinge on the question of his divinity, he would also be the first king called Sōtēr, thus providing the earliest attestation of a cult epithet spreading from the traditional gods to monarchs. The first part of this article will re-examine the king's identity by studying these two texts in connection with other dedications similarly addressed to a 'King Philip' and apparently set up by private individuals. The second will move beyond Macedonia: it will draw on potential parallels from the Attalid, Seleucid and Ptolemaic kingdoms and explore the possible contexts in which individuals set up similar objects. It will be demonstrated that, while there is evidence from other Hellenistic kingdoms of seemingly 'private' dedications set up according to civic or royal commands, in Macedonia the piecemeal and isolated nature of the evidence does not permit a conclusive answer. But whether set up spontaneously or by civic command, these objects provide important evidence for the interaction between the public and the private aspects of ruler worship.

\footnotetext{
* The preparation of this article for publication was made possible by the generous support and research facilities of the Fondation Hardt. I am grateful to Professor Robert Parker, the audiences in the Oxford Epigraphy Workshop and in the Institute of Historical Research (NHRF) in Athens, and the anonymous referees of $C Q$ for valuable comments on earlier drafts.

${ }^{1}$ E.g. S.R.F. Price, Rituals and Power (Cambridge, 1984), esp. ch. 2; F.W. Walbank, 'Monarchy and religion', The Cambridge Ancient History VII.12 (Cambridge, 1984), 84-100; A. Chaniotis, 'The divinity of Hellenistic rulers', in A. Erskine (ed.), A Companion to the Hellenistic World (Oxford, 2003), 431-45 (with bibliography); P.P. Iossif, A.S. Chankowski, C.C. Lorber (edd.), More than Men, Less than Gods: Studies on Royal Cult and Imperial Worship (Leuven, 2011).

${ }^{2}$ C. Veligianni, 'Weihinschrift aus Maroneia für Philip V', ZPE 85 (1991), 138-44, with photo (= SEG XLI 599)

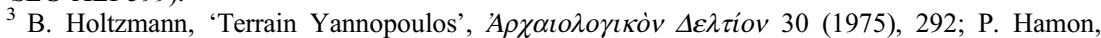
'Études d'épigraphie thasienne, IV. Les magistrats thasiens du IV ${ }^{\mathrm{e}}$ s. av. J.-C. et le royaume de Macédoine', BCH 139-140 (2015-2016), 67-125.
} 


\section{DEDICATIONS TO 'KING PHILIP SŌTĒR'}

Discovered in the area of the 'Porte Maritime' to the west of the ancient agora in Thasos in 1975, the recently published text is carved on a rectangular block of white marble over two lines: [B] $\alpha \sigma \lambda \lambda \dot{\varepsilon} \omega \varsigma, \Phi \curlywedge \lambda \hat{i}[\pi \pi \mathrm{ov}]$ in the first (0.016-metre high) and $\sigma \omega \tau \eta \hat{\rho} \rho \varsigma$ in smaller letters (0.010-metre high) in the centre of the second. Judging from its letter forms, Hamon considers it certain that the text dates to the second half of the fourth century, and accordingly the king must be Philip II of Macedon. The date of the inscription from Maroneia, however, is more difficult to determine. Found in secondary use in the sanctuary of Dionysus at Maroneia during the excavation in 1986, the marble plaque is inscribed in three lines with letters of 0.020-0.025-metres high. Veligianni in the editio princeps argues that the lettering points to Philip V, whereas Hatzopoulos argues for an earlier date and identifies the king with Philip II. ${ }^{4}$ Even if the stone was inscribed during the time of Philip V, he maintains, it could have honoured Philip II posthumously, whose cult might have been renewed under the reign of his homonym and admirer Philip V. ${ }^{5}$ Similar problems of identification have been presented by several other inscriptions mentioning a 'King Philip', with or without the epithet Sōter, from areas under Macedonian influence. I list all of them below for ease of reference:

Thasos, second half of fourth century B.C.: [B] $\alpha \sigma \imath \lambda \dot{\varepsilon} \omega \varsigma$ $\Phi ı \lambda \hat{i}[\pi \pi \mathrm{ov}] \mid \sigma \omega \tau \hat{\eta} \rho \varsigma .^{6}$

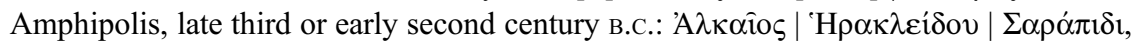

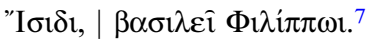

Berga, second century B.C.: $\Delta \mathrm{i}|\kappa \alpha \grave{i} \beta \alpha \sigma \imath \lambda \varepsilon \hat{\imath}| \Phi ı \lambda i \pi \pi \omega .{ }^{8}$

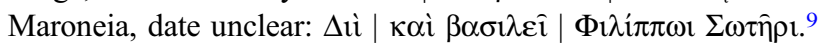

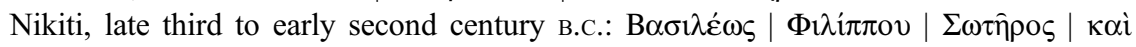

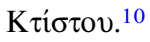

Thasos, before 196 B.C.: B $\alpha \sigma \imath \lambda \varepsilon \hat{\imath}|\Phi ı \lambda i \pi \pi \omega[1]| \Sigma \omega \tau \hat{\eta} \rho[\imath] .{ }^{11}$

The character of these objects is not always clear: while the ones from Nikiti and Thasos are probably small altars, identification of the others is hindered by the often insufficient

\footnotetext{
${ }^{4}$ Veligianni (n. 2), 138: 'Der Buchstabenform nach ist der genannte König Philip V'; cf. M.B. Hatzopoulos, Bulletin Épigraphique (henceforth BE) (1991), no. 377: 'A notre avis, une date plus haute rendrait mieux compte du style de l'écriture.'

${ }^{5}$ M.B. Hatzopoulos, $B E$ (1996), no. 239, in response to C. Veligianni, 'Zu den Inschriften $S E G$ XLI 599 (aus Maroneia) und SEG XXXIX 647 (aus Abdera)', Tekmeria 1 (1995), 191-2.

6 See n. 3.

7 Amphipolis: P. Perdrizet, 'Voyage dans la Macédoine première', BCH 18 (1894), 416-45, at 416-19, no. 1; SIRIS 113; M.B. Hatzopoulos, Macedonian Institutions Under the Kings (Athens, 1996), 2.91-2 no. 75; RICIS 113/0902.

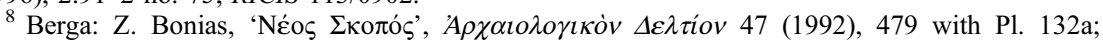
Hatzopoulos (n. 7), 2.92 no. 76; SEG XLVII 917; BE (1998), no. 279. The stone was discovered in the village Neos Skopos, which has been identified with the site of ancient Berga in the Strymon valley: see $B E$ (2000), no. 479; $B E$ (2001), no. 302.

${ }_{9}$ Maroneia: see nn. 2 and 4.

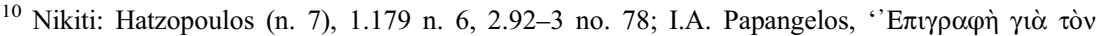

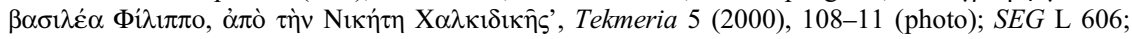
$B E$ (2002), no. 284.

${ }^{11}$ Thasos: C. Dunant and J. Pouilloux, Recherches sur l'histoire et les cultes de Thasos II (Paris, 1958), 230 no. 405, Pl. LIII.2; M.B. Hatzopoulos and L.D. Loukopoulou, Morrylos cite de la Crestonie (Athens, 1989), 47 n. 5.
} 
information in existing publications. ${ }^{12}$ As dedications in the Greek world could take many different forms, and as the distinction between altars and other objects is not important for the purpose here, I have referred to them collectively as 'dedications'. Setting aside the texts from Thasos and Maroneia, the other dedicatory inscriptions have been more or less securely dated to the late third or the second century B.c. on palaeographical grounds; ${ }^{13}$ in the case of the one from Amphipolis, this is confirmed by its reference to Isis and Sarapis, whose cult did not spread to Greece until the Hellenistic period. ${ }^{14}$ To reconcile the chronological gap between the date of the stone and the identity of the king he prefers, Hatzopoulos repeatedly applies the same argument-that an inscription from the reign of Philip V can still refer to Philip IIto almost all of them. ${ }^{15}$ Hatzopoulos's preference for Philip II in all these cases seems to have been influenced by known attestations of divine honours for Philip II, on the one hand, and the supposed lack of such cults of Philip V, on the other. ${ }^{16}$

The deification of Philip II has been a subject of long-standing debate. ${ }^{17}$ Divine honours were possibly bestowed on him by various communities. The people of

12 The genitive case may suggest that the stone from Nikiti and the new one from Thasos were altars. J. Ma, Statues and Cities (Oxford, 2013), 20 n. 22 thinks that the second Thasian text (in the dative) 'might be an altar from a private context'; cf. Hamon (n. 3), 122, who thinks that this concerns not an altar but a dedication. Altars and statue bases can be difficult to distinguish when objects are in a fragmentary state: e.g. A. Benjamin and A.E. Raubitschek, 'Arae Augusti', Hesp. 28 (1959), 65-85, at 65 noted that other scholars have misidentified altars as statue bases; yet, some of their own identifications of altars seem equally uncertain to me.

13 (1) Amphipolis: Perdrizet (n. 7): 'D'après le caractère de l'écriture, le roi est certainement Philippe V'; SIRIS 113, 'Rex est haud dubie Philippus V'; cf. Hatzopoulos and Loukopoulou (n. 11), 47: 'une dédicace d'Amphipolis ... à ne pas douter Philippe II'. (2) Berga: Bonias (n. 8),

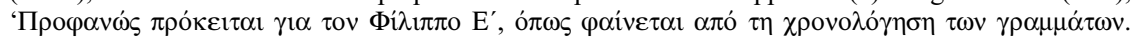

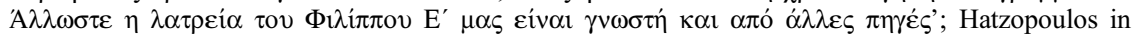
$B E$ (1998), no. 279: 'quoique le monument date indubitablement du $\mathrm{II}^{\mathrm{e}}$ siècle a.C., l'identité du «roi Philippe» n'est pa assurée'. (3) Nikiti: Hatzopoulos (n. 7), 2.92-3 no. 78: 'Although, judging from the letter forms, the inscription belongs to $c a$ 200, the King Philip ... is probably Philip II'; Papangelos (n. 10): 'erected under Perseus for Philip V or (mohr [sic] probably) under Philip V for Philip II'. (4) Thasos: Dunant and Pouilloux (n. 11), 230 no. 405 categorize this under inscriptions before 196 B.c. and think that 'le roi en question est sans aucun doute Philippe V de Macédoine', although they concede that one can hardly determine its date from the letters, which are inscribed irregularly and not very deeply; cf. Hatzopoulos and Loukopoulou (n. 11), 47 n. 5: 'quoique l'écriture de ces deux documents soit peu soignée et irrégulière, on pourrait suggérer une datation aux environs du milieu du IIIe siècle av. J.-C. et, de toute façon, avant la prise de Thasos par Philippe V en 202'. Hamon (n. 3), 120, 123: perhaps later than the newly published Thasian text, but it may be more or less contemporary with it, or several years or even decades later.

${ }^{14}$ On Isis and Sarapis, see e.g. M. Totti, Ausgewahlte Texte der Isis- und Sarapis- religion (Hildesheim, 1985); L. Bricault, Recueil des inscriptions concernant les cultes isiaques (RICIS) (Paris, 2005); L. Bricault, Les cultes isiaques dans le monde gréco-romain (Paris, 2013). The association between Sarapis and Philip V is attested also in RICIS 113/0503.

${ }^{15}$ See Hatzopoulos (n. 7), 2.91-3 nos. 75 (Amphipolis), 78 (Nikiti); BE (1998), no. 279 (Berga); $B E$ (1996), no. 239 (Maroneia).

16 This is expressed most clearly in $B E$ (2002), no. 284 (Nikiti). See also his comments in Hatzopoulos and Loukopoulou (n. 11), 47 n. 3, on attestations of the cult of Philip II in Amphipolis: 'la valeur de ces témoignages a été contestée, à notre avis sans raison.'

${ }^{17}$ E.g. C. Habicht, Gottmenschentum und griechische Städte (Munich, 1970), 12-16; E.A. Fredricksmeyer, 'Divine honours for Philip II', TAPhA 109 (1979), 39-61; E. Badian, 'The deification of Alexander the Great', in H.J. Dell (ed.), Ancient Macedonian Studies in Honor of C.F. Edson (Thessaloniki, 1981), 27-71; E.A. Fredricksmeyer, 'On the background of the ruler cult', in Dell (this note), 145-56; M. Mari, 'The ruler cult in Amphipolis and the Strymon valley', in A. Lakovidou (ed.), Thrace in the Graeco-Roman World (Athens, 2007), 371-86; M. Mari, 'The ruler cult in Macedonia', Studi Ellenistici, vol. 20 (Pisa, 2008), 219-68. 
Amphipolis, according to Aelius Aristides, had been sacrificing to him as a god ("̋ $\theta v o v$ $\dot{\omega} \varsigma \varepsilon \varepsilon \hat{\omega})$ in his lifetime before he captured the city; Clement of Alexandria tells us that

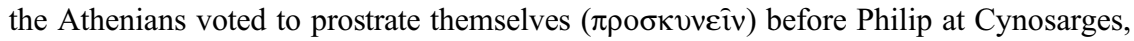
implying perhaps a decision to set up a statue of the king in the shrine. We also hear of altars of Zeus Philippios in Eresos, two temene of Philip in Philippi, and a tribe named Philippeis in Philippopolis. ${ }^{18}$ Yet, it is unclear if these pieces of evidence necessarily imply a divine cult; they are slight and contentious, and some of the literary attestations are of disputed reliability. Precisely because the state of the sources does not permit us any definitive conclusion, there is a danger that one can argue for or against their validity on the divinity of Philip II (or the lack thereof), depending on one's larger arguments about when ruler cults came into being. I therefore prefer to collect them in a footnote and let readers decide for themselves. The new stone from Thasos is unlikely to settle this controversy. Apparently an altar, as the genitive case suggests, it may provide the earliest contemporary evidence for a cult of Philip II during his lifetime; it also shows that Philip was the first king called Sōtēr. Unfortunately, however, the precise character of the cult remains unclear, as is the context in which the altar was set up (see below) and whether Sōtēr here functioned as a regular cult epithet. ${ }^{19}$ The word 'Sōtēr' alone is not a sufficient indication of divinity in itself: only contextual information can help us determine whether a king thus called received divine honours. It is interesting and puzzling why $\Sigma \Omega T H P O \Sigma$ is inscribed in smaller letters in the second line, which was 'peut-être ajoutée dans un second temps', ${ }^{20}$ as if it were an afterthought. Another piece of evidence which describes Philip II as a 'saviour', but without using it as an epithet, is Demosthenes' De Corona in 330 B.c. Demosthenes claims that 'those vile Thessalians and the ill-conditioned Thebans regarded Philip as their friend,

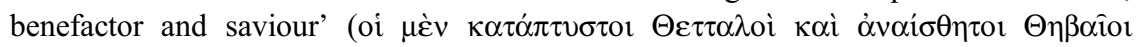

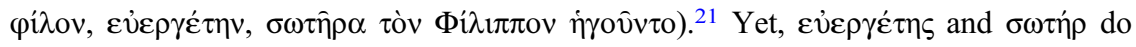
not function here as cult titles in the same way that they did for some later Hellenistic kings, and the passage must not be taken as evidence of a cult of 'Philip Sōtēr' or 'Philip Euergetēs' in Thessaly or in Thebes in the fourth century. Even if a divine cult existed for 'King Philip Sōtēr' in fourth-century Thasos, this need not imply that the words 'King Philip Sōtêr' in other, later dedications must refer to the same Philip. The identity of King Philip Sōtēr in each of the other texts needs to be critically examined on its own.

The dedicatory inscriptions listed above bear some striking resemblances to each other. All of them qualify the king's name with $\beta \alpha \sigma \lambda \lambda \varepsilon v$ s, which, according to the general view, was not used by the Macedonian kings of themselves before Alexander

18 Eresos: OGIS 8a.5-6; Philippi: SEG XXXVIII 658; Philippopolis: IGBulg V 5412; Amphipolis: Aristid. Or. 38.480 p. 715 Dindorf=9.14 Behr; Cynosarges: Clem. Al. Protr. 4.54.5, with R. Parker, Athenian Religion (Oxford, 1996), 257 and n. 4. For cult honours possibly granted at Philip II's own instigation, see Paus. 5.20.9-10 (the 'Philippeum' at Olympia), Diod. Sic. 16.92.5, 16.95.1 (Philip's

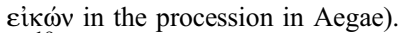

${ }^{19}$ One wonders whether this altar was used for making sacrifice to Philip II. S.R.F. Price, Rituals and Power (Cambridge, 1984), 215-17, when discussing ambiguities associated with imperial sacrifices, warned against the assumption that sacrifices were necessarily made to the dedicands inscribed on the stone. OGIS 332 from Pergamum, for example, mentions a sacrifice on the altar of Zeus Sōtēr $\tau \hat{\omega} \beta \alpha \sigma i \lambda \varepsilon \hat{\imath}$ [sc. Attalus III, line 13].

${ }^{20}$ Hamon (n. 3), 117.

${ }^{21}$ Dem. De Cor. 43 (translation adapted from Loeb), with commentary in H. Yunis, Demosthenes On the Crown (Cambridge, 2001), 134. 
the Great. ${ }^{22}$ Yet, even if $\beta \alpha \sigma i \lambda \varepsilon v \dot{~} \varsigma$ was not a regular part of Macedonian royal titulature under Philip II, this would not have prevented others from referring to him as such, whether during his lifetime or in a later period when the title became official or typical of the Macedonian kings. ${ }^{23}$ The occurrence of $\beta \alpha \sigma \lambda \lambda \varepsilon v \dot{\zeta}$, though seemingly pointing to Philip V, is therefore not a decisive factor when considered alone in itself. When used, however, in Hellenistic inscriptions dated to the late third or early second century as in the present instances (save the new Thasian text), the word would weigh in favour of Philip V. One would expect some other form of qualification, such as the use of his patronymic, if Philip II was referred to at the time of another, reigning king of the same name. Otherwise, it is unclear how contemporary readers could rightly identify the deceased homonym. ${ }^{24}$ The fact that the honorand is simply called 'King Philip' without further qualification (sometimes with the addition of 'Sōtēr') would suggest that his identity must have been obvious to the viewers at the time the dedications were set up, that is, they are likely to have understood it as their present King Philip $\mathrm{V}$, even if it might cause confusion to us.

The association between Philip and Zeus, made in the inscriptions from Maroneia and Berga, is another favourable but not determining factor in identifying the king as Philip $\mathrm{V}$. Though most abundantly documented in the case of Philip V,25 association with Zeus is attested also for other Macedonian kings, including Philip II. ${ }^{26}$ The remaining element in the onomastic formulae, namely the title Sōtēr ('Saviour') in the texts from Maroneia, Nikiti and Thasos, requires more detailed discussion. Traditionally used of the Greek gods, the cult epithet Sōtēr could apply to multiple divinities in the Greek pantheon, and focussed attention on the gods' power to 'save'. ${ }^{27}$ In the Classical period

${ }^{22}$ On the use of the term $\beta \alpha \sigma \imath \lambda \varepsilon v$ 's, see e.g. S. Dow and C.F. Edson, 'Chryseis: a study of the evidence in regard to the mother of Philip V', HSPh 48 (1937), 127-80; A. Aymard, 'Le protocole royal grec et son évolution', REA 1 (1948), 232-63 (reprinted in A. Aymard, Études d'histoire

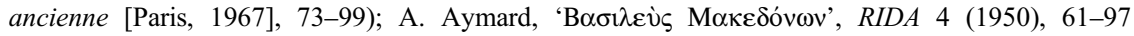

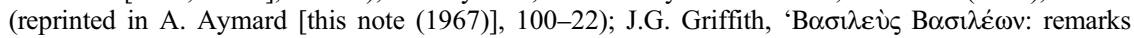
on the history of a title', CPh 48 (1953), 145-54; R.M. Errington, 'Macedonian "royal style" and its historical significance', JHS 94 (1974), 20-37; cf. M.B. Hatzopoulos, 'La letter royale d'Olévéni', Chiron 25 (1995), 163-85, at 171-5.

${ }^{23}$ The word $\beta \alpha \sigma i \lambda \varepsilon v \dot{s}$ was already used of the early Macedonian kings by Greek historians of the Classical period: e.g. Hdt. 8.137-8, 9.44 (Alexander I), Thuc. 2.99 (Perdiccas II). Isocrates (Paneg.

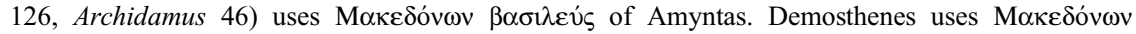
$\beta \alpha \sigma i \lambda \varepsilon i \varsigma$ or M $\alpha \kappa \varepsilon \delta o v i \alpha \varsigma \beta \alpha \sigma \lambda \lambda \varepsilon i \varsigma$ when referring to Macedonian kings in general (to whom he compares Philip II), e.g. in Dem. 1.9, 2.15, 6.20, 7.11. The documents cited in Demosthenes' De Corona,

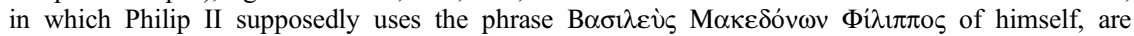
apparently forgeries.

${ }^{24}$ As noted by Mari (n. 17 [2007]), 380.

25 Philip V and Zeus: Hatzopoulos (n. 7), 2.48-9 no. 28 (Philip's dedication to Zeus Meilichios at Pella); Anth. Pal. 16.6 (an epigram comparing Philip to Zeus), Polyb. 7.12 .1 (sacrifice to Zeus on Mt Ithome); Livy 27.30.9 (Philip was elected the $\alpha \gamma \omega v o \theta \dot{\varepsilon} \tau\rceil \varsigma$ of the Nemean Games in honour of Zeus), 40.22.7 (sacrifice to Zeus on Mt Haemus); Plut. Arat. 50 (sacrifice to Zeus on Mt Ithome); M. Holleaux, 'Remarques sur les décrets trouvés dans le sanctuaire de Zeus Panamaros', $B C H$ (1904), 353-63, at 354-6 no. 1 (dedications to Zeus at Panamara in Caria).

${ }^{26}$ Philip II: OGIS 8a.5-6 (altars of Zeus Philippios); G. Le Rider, Le monnayage d'argent et d'or de Philippe II frappé en Macédoine de 359 à 194 (Paris, 1977), 363-4 (tetradrachms of Philip II bearing the head of Zeus). Antigonus Doson (?): SEG XLVIII 812 (altar dedicated to Zeus and to Antigonus Sōtēr and Euergetēs). See also S. le Bohec-Bouchet, 'The kings of Macedon and the cult of Zeus in the Hellenistic period', in D. Ogden (ed.), The Hellenistic World: New Perspectives (London, 2002), 41-57.

${ }^{27}$ E.g. Hdt. 7.192 (Poseidon), SEG XX 707 (Apollo in Cyrene), Paus. 2.31.5 (Dionysos in Trozen), BMC Thrace, 222-4, nos. 67-89 (Heracles in Thasos), Syll. 398 (Zeus Sōtēr in Cos), I.Histriae 11 (the Dioscuri in Histria), Aristid. XLVII (Hieroi Logoi I) 1, 66 (Asclepius), I.Kanais no. 43 (Pan in 
it was occasionally used of powerful individuals who performed exceptional deeds, whether in life or after death, with or without cultic honours. ${ }^{28}$ Its application to Philip II in Thasos is therefore by no means exceptional if we situate Philip along a spectrum: he was preceded by other political figures called 'Saviour', and was followed by other monarchs who acquired it as a formal title along with divine honours. From the early Hellenistic period onwards the epithet spread to an increasing number of kings. ${ }^{29}$ To characterize a king with the epithet Sōtēr was to recognize his performance of functions similar to those by the 'Saviour' gods. These were usually (supposedly) major deeds which profoundly affected the survival, freedom and welfare of the community concerned. The most detailed example accompanied without doubt by divine worship concerns Antigonus I and Demetrius I, who received cult in Athens as Sōtēres on account of their 'liberating' the city from Cassander in 307 B.C. ${ }^{30}$ In what context, then, did Philip (II or V?) become Sōtēr in Maroneia, Nikiti and Thasos?

Strategically located on the coast of Thrace, Maroneia was constantly contested between different powers. It is unclear when precisely Maroneia fell under Philip II's control, though at the latest he must have possessed the city after the battle of Chaeronea in 338 B.c. ${ }^{31}$ Philip V, on the other hand, is known to have twice taken the city, in 200 and in 187/186 B.c. Maroneia was under Ptolemaic possession when Philip V captured and held it under garrison in 200 B.C.; ${ }^{32}$ it was then freed by L. Stertinius in 196 в.C., only to fall under Seleucus III's control from 194 to 189. In the treaty of Apamea between Rome and Antiochus III in 188, Eumenēs II was made master of the Seleucid possessions in the Thracian Chersonese; Maroneia was excluded from Macedonian territory and assigned to no one. ${ }^{33}$ Nevertheless, Philip V took Maroneia again in $187 / 186$. When required by the Roman commissioners to withdraw his garrison in 184, the king, in his anger, had his opponents in Maroneia massacred. He was finally forced to evacuate in $183 .{ }^{34}$ Our sources make no mention of Philip V's 'saving' actions or benefactions (if any) to the Maroneians in either period of Macedonian occupation. None the less, by analogy with other kings honoured as

El-Kanais). Other instances are collected by O. Höfer in W.H. Roscher, Ausführliches Lexikon der griechischen und römischen Mythologie (Leipzig, 1909-1915) 4.1247-72, s.v. Sōtēr.

${ }^{28}$ E.g. Gelon in Syracuse in 480 B.C. (no accompanying cult); Brasidas in Amphipolis in 422 B.C. (posthumous hero cult); Dion in Syracuse in 357-356 B.c. (heroic or divine cult in life).

${ }^{29}$ I list here some of the kings documented as Sōtēr. Among the Antigonids: Antigonus I Monophthalmus, Demetrius I Poliorcētēs, Antigonus II Gonatas and Antigonus III Doson. The Seleucids: Seleucus I, Antiochus I, Antiochus II, Antiochus III, Antiochus IV, Demetrius I, Demetrius III. The Attalids: Attalus I, Eumenēs II, Attalus II.

30 See n. 42 below.

${ }^{31}$ Dem. 12.17 mentions the Athenians forcing Thasos and Maroneia to submit their dispute over Stryme to arbitration; this leads N.G.L. Hammond and F.W. Walbank, A History of Macedonia (Oxford, 1972-1988), 2.266, 2.379 to think that Maroneia was still an Athenian ally in 340 B.C. (when Philip II's letter in Dem. 12 was supposedly written), and that it probably did not come under Philip's control until 338. The date 338 is also adopted by Hatzopoulos in BE (1991), no. 377. However, Veligianni (n. 5), 191 points out that Maroneia's dispute with Thasos actually dates to $361 / 360$, not 340 , and it is possible that Philip took the city (precise date unknown) earlier than 338 .

32 Conquest in 200 B.c.: Livy 31.16.4; F.W. Walbank, Philip V (Cambridge, 1940), 133, 142 n. 2 , $180,315$.

33 Polyb. 21.46.9; Livy 38.39.14, 39.27.10. Walbank (n. 32), 216, 218.

34 Philip's second period of occupation: Polyb. 22.6, 22.13-14, 23.1.4, 23.8.1-2; Livy 39.24.6-14 (expanded version of Polyb. 22.6), 39.27.2-39.29.2, 39.34.1-10, 39.46.9, 39.53.10-11. Walbank (n. 32), 223-7, 232-5, 237, 240-1, 260; Hammond and Walbank (n. 31), 3.454-7, 3.468. 
Sōtēr when they took over a city from another power, ${ }^{35}$ Philip V could probably have claimed to have 'liberated' Maroneia from Ptolemy V in 200 B.c. If cult epithets, along with other cultic honours, formed part of the process by which a community came to terms with a new power, ${ }^{36}$ Philip V is more likely to have been honoured as Sōtēr when he first captured the city in 200, rather than upon his return in 187/186. ${ }^{37}$ In the absence of further contextual details, however, this should remain hypothetical.

Off the Macedonian coast and not far from Maroneia, Thasos was taken by Philip II probably in $340 / 339$ B.C. with the help of Thasian supporters, and was a member of the League of Corinth in $338 .{ }^{38}$ The context for the setting up of the fourth-century inscription $[\mathrm{B}] \alpha \sigma \iota \lambda \dot{\varepsilon} \omega \varsigma \Phi \uparrow \lambda \hat{i}[\pi \pi \mathrm{ov}] \mid \sigma \omega \tau \hat{\eta} \rho \varsigma_{\varsigma}$ cannot be ascertained given the lack of contextual information. According to Hamon, it was possibly set up by the partisans of Philip II in Thasos and their leader Aristoleos, who is mentioned in Demosthenes' De Corona as a pro-Macedonian enemy of Athens, and whose name is listed in a fourth-century section in the 'Great List of Theoroi' in the agora of Thasos. Hamon further attributes to Philip II the second, and possibly later, Thasian dedication inscribed B $\alpha \sigma \imath \lambda \varepsilon \hat{\imath}|\Phi \imath \lambda i \pi \pi \omega[1]|$ $\Sigma \omega \tau \hat{\eta} \rho[\imath]$, which he thinks is more or less contemporary with the newly published text or several years or decades later, and he sees Philip II Sōtēr as the unnamed honorand of the Thasian festival $\Sigma \omega \tau$ ípi $\alpha$, which has traditionally been connected to Heracles, that is, the ancestor of the Macedonian king. ${ }^{39}$ However attractive this reconstruction may be, the presence of Philip II Sōtēr in Thasos in the late fourth century need not exclude the possibility that, a little more than a century later, his successor Philip V might have borne the same title in the same place.

Thasian history in the third century is poorly documented, ${ }^{40}$ but we know that the city was independent when taken by Philip V in 202 B.C., and there is contextual evidence to suggest that Philip V is a likely recipient of the second Thasian dedication. Polybius tells how, when the king put in at Thasos, the Thasians agreed to surrender the city if he would let them remain ungarrisoned, exempt from tribute, without soldiers

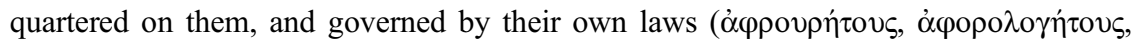

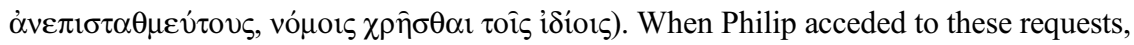
everyone present applauded what was said with a loud cry and ceremonially led Philip

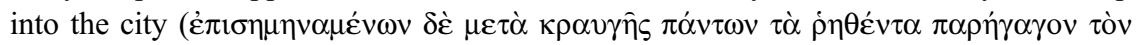

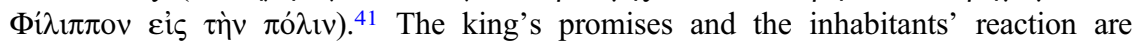
strikingly similar to the popular reception documented for Demetrius I at Athens about a century earlier. On sailing into the harbours in 307 Demetrius announced his intention to set Athens free, to expel Cassander's garrison, and to restore their laws

35 E.g. Demetrius I's 'liberation' of Athens from Cassander in 307 B.C. (Plut. Dem. 9.1, 10.3); Seleucus I's and Antiochus I's takeover of Aegae from Lysimachus in 281 B.C. (SEG LIX 1406 A).

36 Price (n. 19), esp. ch. 2.

${ }^{37} \mathrm{Cf}$. Veligianni (n. 2), who thinks that the second period of Philip V's occupation is concerned.

38 Dem. De Cor. 197; IG II ${ }^{3} 318.44=$ RO 76.b.5; G. Reger, 'Thasos', in M.H. Hansen and T.H. Nielsen, An Inventory of Archaic and Classical Poleis (Oxford, 2004), no. 526; cf. J. Pouilloux, Recherches sur l'histoire et les cultes de Thasos I (Paris, 1954), 433-4.

39 Dem. De Cor. 197. Hamon (n. 3), 112-23. The other Thasian dedication: Dunant and Pouilloux (n. 11), 130 no. 405. Its date and the king's identity have been disputed: see n. 13. The much-defaced side B of the stone, in which only a minimum of letters have survived according to Hamon's reading, is too insecure to be used for any purpose. $\Sigma \omega \tau \eta \dot{\rho t \alpha}$ festival: F. Salviat, 'Une nouvelle loi thasienne: institutions judiciaires et fêtes religieuses à la fin du IVe sièle av. J.-C.', BCH 82 (1958), 193-267, esp. 228-32; LSS 69.

40 See J. Pouilloux (n. 38), 434-7.

${ }^{41}$ Polyb. 15.24.1-3; Walbank (n. 32), 115-17; Hammond and Walbank (n. 31), 2.413. 
and ancestral constitution to the Athenians. 'Most of the people at once threw their shields down in front of them, and with clapping of hands and loud cries urged

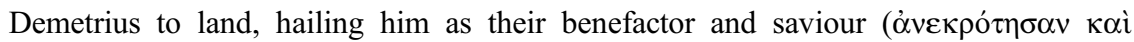

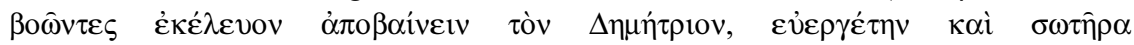
$\pi \rho 0 \sigma \alpha \gamma о \rho \varepsilon v \dot{0} \tau \tau \varsigma)$. Sōtēr became the official title bestowed upon Demetrius and his father by the Athenians shortly afterwards. ${ }^{42}$ The Thasian inscription B $\alpha \sigma \lambda \boldsymbol{\varepsilon} \hat{\imath}$ । $\Phi 1 \lambda i \pi \pi \omega[1] \mid \Sigma \omega \tau \hat{\rho} \rho[1]$ might have been related to the events of 202: Philip's promise to respect the city's liberty (Polyb. 15.24.4: غं $\lambda \varepsilon v \theta \varepsilon \rho i \alpha)$ might have earned him the title of Sōter. Compared to the more commonly found dedications set up on the kings' behalf (i $\pi \varepsilon \dot{\rho}$ followed by the genitive case) or in their honour (accusative), ${ }^{43}$ the use of the dative case in this text (and in the texts from Maroneia and Berga) carries very different significance: it recognizes implicitly the monarch's divinity; he could receive dedications in his own right as if he were a god. ${ }^{44}$ If it is correct to contextualize this dedication in the events of $202,{ }^{45}$ this would be an interesting example of a Hellenistic king honoured as Sōtēr, not on account of any 'saving' performed but because of his promises to maintain the present liberty of an independent city. Despite his promises, however, after gaining entry Philip seized the city, enslaved the population and held it with a garrison. This led Polybius to reflect on the fact that perhaps all kings, despite their initial talks of $\dot{\varepsilon} \lambda \varepsilon v \theta \varepsilon p i \alpha$, would quickly mistreat those who trust them. ${ }^{46}$ If erected after the city had fallen, this inscription might have been an attempt to propitiate the king or to show the citizens' allegiance. Alternatively, one may suppose some royal intervention or concession not documented during his period of control. After Philip's defeat by Rome in 196 в.c. Thasos was freed from Macedonian domination. ${ }^{47}$ It may not be a coincidence that, in the following decade, coins bearing the legends HPAK $\Lambda$ EOr $\Sigma \Sigma \Omega T H P O \Sigma$ OA $\Sigma I \Omega N$ were minted in Thasos, and contemporary with them were coins inscribed $\Delta \mathrm{ION} Y \Sigma$ Or $\Sigma \Omega T H P O \Sigma$ MAPSNITSN in Maroneia. ${ }^{48}$ Scholars have seen in the very similar coin-types

42 Plut. Dem. 9.1 (trans. adapted from Loeb), 10.3; discussed in e.g. K. Scott, 'The deification of Demetrius Poliorcētēs. Part I', AJPh 49 (1928), 136-66; K. Scott, 'The deification of Demetrius Poliorcētēs. Part II', AJPh 49 (1928), 217-39; Habicht (n. 17), 44-55; V.J. Rosivach, 'The cult of Zeus Eleutherios at Athens', PP 42 (1987), 262-85; J.D. Mikalson, Religion in Hellenistic Athens (Berkeley and London, 1998), esp. 75-104; A. Kuhn, 'Ritual change during the reign of Demetrius Poliorcētēs', in E. Stavrianopoulou (ed.), Ritual and Communication in the Graeco-Roman World (Liège, 2006). Cf. also the reception of Pelopidas and his comrades in the 370s in Plut. Pel. 12.4: the assembly, at the sight of their entrance, rose to its feet and with shouts and clapping of hands,

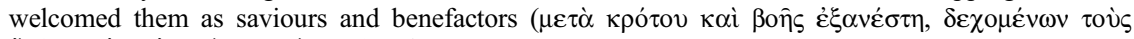

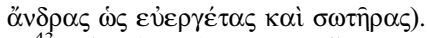

43 Price (n. 19), 209-20 discusses the distinction between sacrifice to and sacrifice vंź $\rho$ rulers. On the grammar of dedicatory formulae, see also P. Veyne, 'Les honneurs posthumes de Flavia Domitilla', Latomus 21 (1962), 49-89, at 68-81 (on the influence between the Latin dative and the Greek accusative in dedicatory formulae); Ma (n. 12), 17-24; T.S.F. Jim, 'On Greek dedicatory practices: the problem of hyper', GRBS 54 (2014), 616-37.

${ }^{44}$ Even in the Hellenistic period the dative remains relatively rare for monarchs. Some examples are SEG XLIV 1507; SB I 1104; IG XII.3 1387; OGIS 62, 82; SEG XII 308; SEG II 867.

45 Dunant and Pouilloux (n. 11), 230 no. 405 categorize this under inscriptions before 196 B.C., that is, before the city's liberation by the Romans.

46 Polyb. 15.24.4-6.

47 Polyb. 18.44; Livy 33.30.3; Walbank (n. 32), 179; Hammond and Walbank (n. 31), 3.446.

48 Thasos: BMC Thrace, 222-4 nos. 67-89; B.V. Head, Historia Numorum (Oxford, 1911²), 264-6; G. Le Rider, 'Les monnaies thasiennes', in G. Daux (ed.), Guide de Thasos (Paris, 1967), 185-92, at 189-91, with P1. 4, nos. 51-2 (from c.180 B.c.); Y. Grandjean and F. Salviat, Guide de Thasos 
commercial or some other sort of ties between the two cities. ${ }^{49}$ Might the coins have been minted to celebrate their liberation from Philip V Sōtēr? ${ }^{50}$

The modern village of Nikiti in the Sithonia peninsula, where the altar 'of King

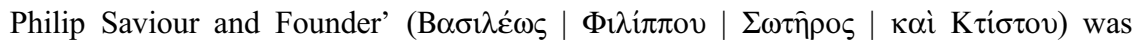
found, is situated a few kilometres north of the ancient city of Gale, also known as Galepsus. ${ }^{51}$ During the reign of Philip II the Chalcidic League was broken up, and many cities of the Chalcidice fell under Macedonian control; nevertheless, much remains uncertain about the status of these cities, the treatment they received and their relations to Macedonia thereafter, which doubtless varied from one case to another. ${ }^{52}$ Since we do not know of a city founded by Philip II or Philip V in this region, ${ }^{53}$ Hatzopoulos and Papangelos prefer to relate 'Saviour' and 'Founder' to the foundation of the entire Macedonian kingdom by Philip II, who, according to Justin, formed one kingdom and one people from large numbers of different clans and tribes. ${ }^{54}$ Assuming that no cult of a living king is attested in Macedonia, Papangelos further suggests that the stone was erected under Perseus for Philip V or, more probably in his view, under Philip V for Philip II. ${ }^{55}$ As Mari rightly points out, however, the word 'founder' might have been used figuratively, that is, it need not refer to any specific acts of foundation by the king concerned. We can think of Brasidas, who was honoured posthumously as 'founder' (oikı Amphipolitans were transferring the existing cult honours of Hagnon (the Athenian who founded the city in 437 B.C.) to Brasidas, although Brasidas had not in fact founded the city. ${ }^{56}$ Similarly, Aratus, who liberated Sicyon from Nicocles' tyranny in 251 B.C.,

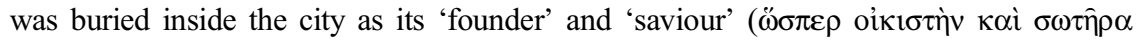

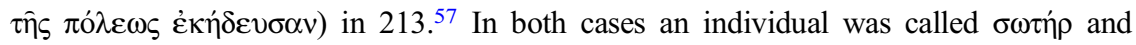

(Athens, 2000), 310-11. Maroneia: E. Schönert-Geiss, Griechisches Münzwerk: die Münzprägung von Maroneia (Berlin, 1987), Textband 64-85, Tafelband 37-91 (c.189/188 - 49/45 B.c.).

${ }^{49}$ Dunant and Pouilloux (n. 11), 6 n. 1: 'cette analogie paraît bien avoir été déterminée par des nécessités commerciales'; Le Rider (n. 48), 190 n. 1: 'les dieux monnayages ont été inaugurés à la suite d'un même événement qui intéressait les deux cités'; Grandjean and Salviat (n. 48), 311: 'il faut sans doute y voir l'effect d'une alliance monétaire'.

${ }^{50}$ I owe this observation to Veligianni (n. 2), 143-4, but she does not link the Maroneian material to Philip V's dealings with Thasos and the Thasian dedication.

${ }^{51}$ P. Flensted-Jensen, 'Gale(psos)', in Hansen and Nielsen (n. 38), no. 571. This is not to be confused with the Thasian colony Galepsus near the Strymon, which was destroyed by Philip II in 356 B.c. (Strabo 7 fr. 35): see Hansen and Nielsen (n. 38), no. 631.

52 See A.B. West, The History of the Chalcidic League (Madison, 1918), 115-37; M. Zahrnt, Olynth und die Chalkidier (Munich, 1971), ch. 3; Hammond and Walbank (n. 31), 2.365-79; Hatzopoulos (n. 7), 1.189-99; S. Psoma, Olynthe et les Chalcidiens de Thrace: études de numismatique et d'histoire (Stuttgart, 2001), 240-9.

53 The nearest new Hellenistic settlements in the region were Cassandreia and Antigoneia, the former of which was located in an extensive territory including estates previously granted by Philip II and Alexander the Great (Syll. ${ }^{3}$ 332): see G.M. Cohen, The Hellenistic Settlements in Europe, the Islands, and Asia Minor (Berkeley and Oxford, 1995), 91-2, 95-9.

54 Justin 8.6.2; Hatzopoulos (n. 7), 1.179, 2.92-3 no. 78, probably followed by Papangelos (n. 10).

55 Recently Mari ([n. 17 (2008)], 262-3 on this inscription) has argued against the view that no ruler cult, at least as far as living kings are concerned, ever existed in Classical or Hellenistic Macedonia.

56 Thuc. 5.11.1. On the cult of Brasidas at Amphipolis, see I. Malkin, Religion and Colonisation in Ancient Greece (Leiden, 1987), 228-32; S. Hornblower, A Commentary on Thucydides (Oxford, 1996), 2.449-56 (with bibliography); B. Currie, Pindar and the Cult of Heroes (Oxford, 2005), 164-5; C. Jones, New Heroes in Antiquity (Harvard, 2010), 24-6.

57 Plut. Arat. 53; see also Paus. 2.9.4; A. Griffin, Sikyon (Oxford, 1982), 79-81. For Hellenistic kings called Sōtēr and Ktistēs, see e.g. OGIS 301 (Eumenēs II); I.Estremo Oriente 103 (Antiochus IV). 


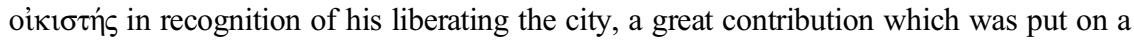
par with, but did not actually involve, city foundation. The word oikı бтńs was used much more frequently in the Classical period than $\kappa \tau i \sigma \tau \eta \zeta$, which is attested occasionally from the fourth century onwards and became extremely common in the Roman period. ${ }^{58}$ Even if $\kappa \tau i \sigma \tau\rceil$ does not necessarily refer to actual 'founding', it nevertheless remains difficult to relate Philip's epithets to other deeds (if any), since little is known about Philip's dealings either with Gale(psus) or with its nearby areas.

We have seen the possible contexts in which Philip V could have been honoured as Sōter in various communities, yet in the later Hellenistic period a specific context is not strictly necessary. When used of Alexander's early successors (as in the cases of Demetrius I, Ptolemy I, Seleucus I and Antiochus I), Sōtēr invariably referred to specific deeds of the kings: it was not kingly status per se which made a king 'Sōtēr' but his performance of 'saving' functions for the $\sigma \omega \tau \eta p^{\prime} \alpha$ or the $\dot{\varepsilon} \lambda \varepsilon v \theta \varepsilon \rho i \alpha$ of the community. We can only speculate what exceptional 'saving' act was performed by Philip II in fourth-century Thasos. By the late third and early second centuries B.C., however, the epithet Sōtēr had become increasingly routine: communities probably felt compelled to use a title which had become fairly common if not standard in the treatment of Hellenistic monarchs. Instead of responding to a particular 'saving' act performed, a king might be honoured under this title because of his potential to do good (and harm). Among the Antigonids alone, Antigonus I Monophthalmus, Demetrius I Poliorcētēs, Antigonus II Gonatas and Antigonus III Doson are known to have received the title Sōtēr. ${ }^{59}$ By the time Philip V came to power, this had become a fairly standard way of showing respect for a king, and the very fact of his ruling over the Chalcidice might have been a sufficient reason for honouring him as such. Although much remains unclear about the precise context in which these dedications were set up, taken together,

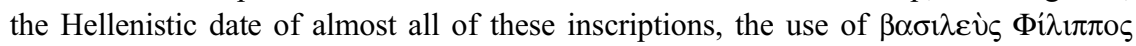
without further qualification, the well-documented association between Philip $\mathrm{V}$ and Zeus, and the prevalence and routinization of Sōter as a royal epithet by the late third century в.C., all weigh in favour of Philip V as the 'King Philip Sōtēr' in the texts from Maroneia, Nikiti and the possibly later one from Thasos.

After the defeat of Philip V in the Second Macedonian War, the Roman general Flamininus famously proclaimed the freedom of the Greeks in the Isthmian Games of 196 B.c. In the flurry of public excitement everyone sprang forward to hail him as the

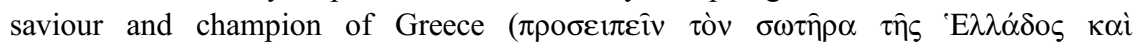
$\pi \rho o ́ \mu \alpha \chi o v) .{ }^{60}$ At more or less the same time in Thessaly, where much of the campaigning (including the decisive battle at Cynoscephalae) took place, a penteteric festival called the 'E $\lambda \varepsilon v \theta \varepsilon \dot{p} \rho \alpha$ was established in Larisa in honour of Zeus Eleutherios, the very god with

58 See W. Leschhorn, Gründer des Stadt (Stuttgart, 1984); M. Casevitz, Le vocabulaire de la colonisation en grec ancien (Paris, 1985), esp. 69-70; F. Muccioli, Gli epiteti ufficiali dei re ellenistici (Stuttgart, 2013), 201-2. In the Roman period numerous altars were set up to Hadrian as Sōtēr and Ktistēs: see n. 73.

59 Antigonus I and Demetrius I: Plut. Dem. 10.3, Diod. Sic. 20.46.2, SEG XXX 69. Antigonus II Gonatas: V.C. Petrakos, $\Delta \hat{\eta} \mu o \varsigma \tau o \hat{v} P \alpha \mu v o \hat{v} v \tau o \varsigma$ (Athens, 1999), no. 7 and possibly IG XII Suppl. 168. Antigonus III Doson: Polyb. 5.9.10, 9.36.5, IG V.2 229, IG V.1 1122 and possibly SEG XLVIII 812 (Gonatas has also been suggested as the king in question).

${ }^{60}$ Plut. Flam. 10.5; see similarly Polyb. 18.46.12, with Walbank's commentary ad loc. He was also honoured as Sōtēr in Chalcis (Plut. Flam. 16.4), Gytheum (Syll. ${ }^{3}$ 592) and Acrocorinth (Livy 34.50.9). 
whom Philip identified himself. ${ }^{61}$ If it is correct to think that Philip V was formerly Sōtēr in various communities, to call Flamininus Sōtēr and to honour Zeus Eleutherios as a symbol of collective Greek freedom might have been a deliberate insult to Philip and a negation of the $\sigma \omega \tau \eta p i \alpha$ he supposedly provided.

\section{'PRIVATE' DEDICATIONS TO HELLENISTIC KINGS: CONTEXTS AND MOTIVATIONS}

The dedications to Philip Sōtēr raise important questions of the identity of their dedicators and their possible motivations. Of the inscriptions cited earlier, only the one from Amphipolis indicates the dedicator's name; ${ }^{62}$ yet, the size and the limited scale of all these objects and, in the second Thasian dedication, the quality of the craftsmanship and the error of the stonecutter suggest that they are very likely to have been brought by private individuals. ${ }^{63}$ These dedications have received far less discussion than public cults and civic monuments set up by cities and, given their simple and often anonymous nature, can easily escape our attention.

The phenomenon is, however, not unique to Philip II and Philip V. Similar dedications are documented for other Hellenistic kings, such as Attalus I and Eumenēs II: ${ }^{64}$

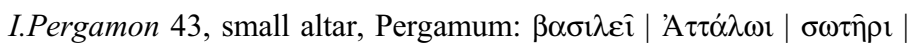

'A $\pi \mathrm{o} \lambda \lambda \mathrm{ó}_{\delta} \omega \mathrm{\rho}[\mathrm{o} \varsigma]$.

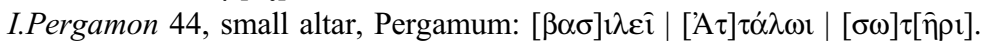

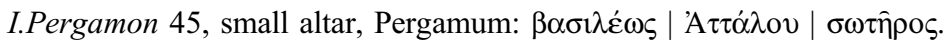

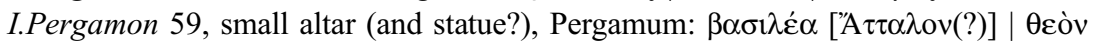

$\sigma \omega[\tau \hat{\eta} \rho \alpha \kappa \alpha \grave{i}]$ | òv $\beta \omega \mu$ ò $[v\{\dot{o} \delta \varepsilon \hat{i} v \alpha\}]$.

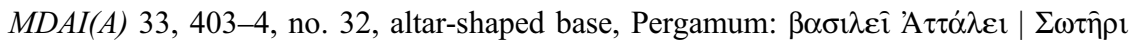

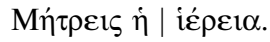

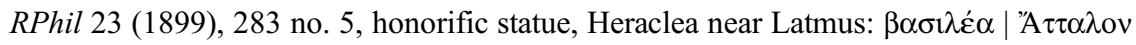
| $\Sigma \omega \tau \hat{\eta} \rho \alpha$.

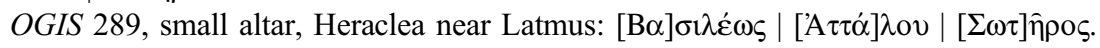

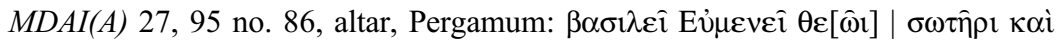

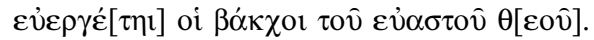

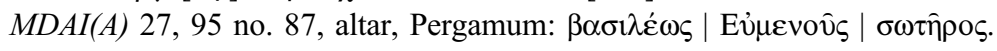

Formulated so similarly to each other and to the ones for Philip Sōtēr, these altars and statue bases are interesting but also frustratingly unrevealing. All that is stated-mostly

${ }^{61}$ On the 'E $\lambda \varepsilon v \theta \varepsilon \dot{\varepsilon} 1 \alpha$ at Larisa, see K.J. Gallis, 'The games in ancient Larisa: an example of provincial Olympic Games', in W.J. Raschke (ed.), The Archaeology of the Olympics (London, 1988), 217-35; D. Graninger, Cult and Koinon in Hellenistic Thessaly (Leiden, 2011), 67-85, with 159-82. See also F.W. Walbank, 'Alcaeus of Messene, Philip V, and Rome', CQ 36 (1942), 134-45, at 145 n. 1 and F.W. Walbank, 'Alcaeus of Messene, Philip V, and Rome (concluded)', CQ 37 (1943), 1-13, at 8 n. 7, who thinks that the honours for Flamininus and Zeus Eleutherios, using the same titles given to Zeus after the battle of Plataea, were deliberate appropriations of Philip V's pretensions and an assimilation of Philip to the barbarians.

62 Amphipolis: see n. 7.

${ }^{63}$ Size of dedications: Amphipolis: $0.20 \times 0.22 \mathrm{~m}$; Berga: $0.30 \times 0.26-0.33 \times 0.09 \mathrm{~m}$; Maroneia: $0.36 \times 0.35 \times 0.13 \mathrm{~m}$; Nikiti: $0.61 \times 0.32 \times 0.28 \mathrm{~m}$; Thasos: $0.13 \times 0.205 \times 0.28 \mathrm{~m}$ (first dedication), $0.137 \times 0.19 \times 0.165 \mathrm{~m}$ (second dedication).

${ }^{64}$ Private dedications to the Ptolemies (in the dative) are also attested, and are often more elaborate in formulae: e.g. OGIS 24, 62-3, 82, 102-3, 106, 111, 732; SB 1.1104, 3993; SEG II 867, XX 509, XXIV 1174, XLIV 1507; see also P.M. Fraser, Ptolemaic Alexandria (Oxford, 1972), 1.233-6. 
in the dative case, occasionally in the genitive or in the accusative-are the king's name, his title $\beta \alpha \sigma i \lambda \varepsilon v$ s, his epithet Sōtēr and, in a few cases, the dedicator's identity. We find a priestess called Metreis and a group of Dionysiac associates in Pergamum. ${ }^{65}$ Although none of the inscriptions indicates the occasion when it was set up, contextual evidence suggests that they were erected after Attalus I and Eumenēs II defeated the Gauls in the 230s and 180s respectively: ${ }^{66}$ they earned the title Sōtēr as a result of their successful defence and protection of their subjects. Epigraphic and literary sources describe the savage and violent nature of the Celtic invaders: how they desecrated temples and shrines, set fire to farms and houses, killed women and children alike, and took many inhabitants prisoners. ${ }^{67} \mathrm{~A}$ marble stēle found in Thyateira, firmly dated to 276/ 275, shows a father giving thanks to Apollo Pityaenos for the release and safe return ( $\sigma \omega \tau \eta \rho^{\prime} \alpha$ ) of his son, who had been captured by the Galatians. ${ }^{68}$ The threat posed by the Gauls in Asia Minor was therefore dire and real, and these dedications were responses to deliverance from a real crisis. Did individuals, otherwise helpless to defend themselves, offer dedications to their kings as a token of their respect and recognition in return for protection received? Unfortunately, they have left no explicit statement of thanks and hope addressed to the monarchs, and their motivations remain difficult to pin down.

That the dedications for Attalus I and Eumenēs II concentrate in Pergamum may itself be significant. We would like to know whether they were originally set up in the same area $^{69}$ and on the same occasion-such as some celebration in the capital upon the kings' triumphant return or a ceremony during which Attalus I was acclaimed 'king' and 'saviour'. ${ }^{70}$ Our literary sources do not document the rituals (if any) on the kings' return after defeating the Gauls. But an analogy may be drawn with Attalus I's reception in Athens in 200 B.C. Polybius tells us that, in response to an Athenian request for help against Philip V, Attalus I arrived at Athens and was met not only by magistrates and cavalrymen but also by all the citizens with their wives and children, which demonstrated the $\varphi \imath \lambda \alpha v \theta \rho \omega \pi i \alpha$ of the populace. All the temples were thrown open, victims were placed ready at all the altars, and the king was asked to offer sacrifice. ${ }^{71}$ Could it be that Attalus I

${ }^{65} L G P N$ Va, s.v. Metreis (6).

66 On Attalus I's defeat of the Gauls, see E.V. Hansen, The Attalids of Pergamon (Ithaca, New York, 1947), 28-38; É. Will, Histoire politique du monde hellénistique (323-30 av. J.-C.) (Nancy, 1979-1992), 1.196-7; R.E. Allen, The Attalid Kingdom (Oxford, 1983), ch. 5. Eumenēs II: the main source is a decree from Telmessus in Lycia in 184 B.C., which describes him as

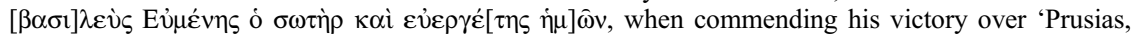
Ortiagon, and the Galatians and their allies': see G. Jacopi, 'Nuove epigrafi dalle Sporadi meridionali', Clara Rhodos 2 (1932), 169-255, at 172-4 no. 3; Polyb. 22.21; Trogus, Prol. 32.

${ }^{67}$ See e.g. I.Priene $17=$ I.Priene 28 (Priene's honorific decree for Sotas); I.Laodikeia no. 1 (decree from Laodicea honouring Achaeus and his agents for services during the Gallic war); Paus. 10.22.3-4. See also S. Mitchell, Anatolia: Man, Land and Gods in Asia Minor (Oxford, 1993), 1.17. ${ }^{68}$ TAM V.2 no. 881.

69 Of the five altars in Pergamum for Attalus I, four came from the acropolis, but each had a different find-spot (the agora, the theatre, the sanctuary of Demeter, the sanctuary of Athena), and the fifth came from the sanctuary of Aspordene in the mountain round Pergamum.

${ }^{70}$ Attalus I was given the title 'king' after his Gallic victory: Polyb. 18.41.7 (= Livy 33.21.3); Livy 38.16.14; Strabo 13.4.2, 624. It is sometimes thought that the B $\alpha \sigma^{\prime} i \lambda \varepsilon 1 \alpha$ mentioned in OGIS 268 were games instituted to celebrate Attalus I's assumption of the title of king (e.g. W. Dittenberger in OGIS; U. Wilcken, 'Attalos I', RE 2 [1896], 2159; E. Meyer, Die Grenzen der Hellenistischen Staaten in Kleinasien [Zurich, 1925], 98); but L. Robert, 'Inscriptions grecques inédites au Musée du Louvre', RA 2 (1933), 121-47, at 136 and L. Robert, Villes d'Asie Mineure (Paris, 1962), 36 n. 6 showed that the festival was held in honour of Zeus Basileus; cf. Allen (n. 66), 105 n. 120.

${ }^{71}$ Polyb. 16.25, Livy 31.14.12. 
and Eumenēs II, upon returning to Pergamum, were greeted by citizens who had set up altars in their honour and upon which sacrifice would be performed as an expression of their goodwill and $\varphi \imath \lambda \alpha v \theta \rho \omega \pi i \alpha$ ? Similar receptions are documented for Ptolemy III in the Gourob papyrus. In 246 B.c. at the beginning of the Third Syrian War, when Ptolemy III and his company arrived at Seleuceia, they were greeted by priests, magistrates, soldiers and other citizens wearing garlands. According to Holleaux's supplements, private citizens asked them to sacrifice victims on the altars they had built by their

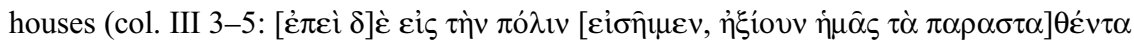

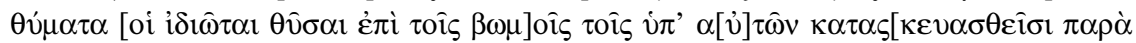

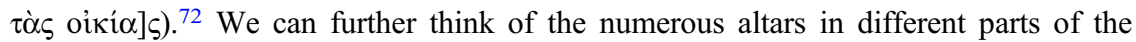
Greek world for Hadrian as Sōtēr and Ktistēs in the second century A.D.: these are generally interpreted as a Greek response to the emperor's appearance in person on his travels. ${ }^{73}$ Although similar receptions are not documented for the Attalids after their Galatian victories, the parallels offered by Attalus I, Ptolemy III and Hadrian in Greece make it probable that the kings' physical presence or $\dot{\varepsilon} \pi \_\delta \mu i \alpha$ might have prompted these objects.

Despite these dedications' seemingly private character, it is far from clear whether they were set up on individuals' own initiative or following civic or royal commands. Evidence from the Seleucid and Ptolemaic kingdoms suggests that members of citizen bodies might be required to set up domestic altars. According to a decree from Teos concerning the local cult of Antiochus III and Laodice III, each of the $\sigma v \mu \mu$ opior (civic subdivisions) had to build an altar of the royal couple, and all others who live in the city (presumably meaning foreign residents) had to sacrifice and celebrate the festival in their own houses according to their means. ${ }^{74}$ Here the initiative came from the subject city, but similar commands could also be issued by the king himself. When recounting the Jewish struggle for religious and political independence from 175 to 135 B.C., the first book of the Maccabees records Antiochus IV Epiphanēs' decree to his whole kingdom ordering, inter alia, the construction of altars for sacrifice

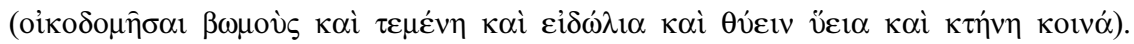
Not only were altars constructed in the cities of Judah all around, local inhabitants

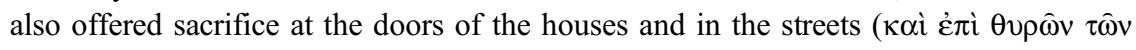

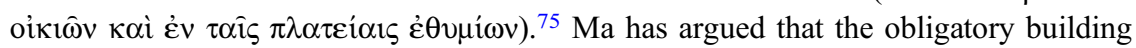
of altars in front of houses, along with compulsory participation in civic festivals, does not constitute religious 'persecution' of the Jews but a standard administrative

72 W.Chr. no. 1, esp. col. II 23-5, col. III 3-5 (reception at Seleuceia), 19-25 (similar reception at Antioch), with supplements and discussion in M. Holleaux, Études d'épigraphie et d'histoire grecques III (Paris, 1942), 281-310 (308-9 on the reception of kings). The lines quoted were supplemented by Holleaux on the analogy of I.Magnesia $100=$ LSAM 33, according to which sacrifices should be made to Artemis Leucophryene by each of the inhabitants before the door, according to the means of the households, on altars constructed by them (A. lines 7-10: ; see also 87-8). On altars in or outside private houses, see also C.G. Yavis, Greek Altars (St. Louis, 1949), 175-6; A. Pelletier, 'Note sur les mots

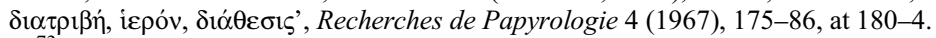

${ }^{73}$ Altars for Hadrian: W. Weber, Untersuchungen zur Geschichte des Kaisers Hadrianus (Leipzig, 1907), 134, 188, 205; A.S. Benjamin, 'The altars of Hadrian in Athens and Hadrian's Panhellenic program', Hesp. 32 (1963), 57-86; Price (n. 19), 69. Numerous (private?) altars are similarly documented for Pompey, Augustus and Trajan. All of them are small in scale, usually anonymous and formulated similarly. On altars for Augustus, see Benjamin and Raubitschek (n. 12).

74 SEG XLI 1003, II.9-13, 24-5; J. Ma, Antiochos III and the Cities of Asia Minor (Oxford, 1999), 311-17 no. 18, with discussion in A. Chaniotis, 'La divinité mortelle d'Antiochos III à Téos', Kernos 20 (2007), 153-71. The date is disputed: Ma prefers c.203 в.c. to $197 / 196$ в.C.

${ }^{75}$ I.Macc. $1.47,1.55$. 
measure for integrating the subject community into the Seleucid city of Antiocheia, a phenomenon also attested in the decrees of various Hellenistic poleis. ${ }^{76}$ Here we are not told whether the sacrifices were offered to Antiochus or to the Greek gods, but an Alexandrian decree concerning the cult of Arsinoē II Philadelphus attests to the construction of household altars for private sacrifices to the queen. It stipulates that 'those who wish to sacrifice to Arsinoē Philadelphus are to sacrifice in front of their shrines (?) or on the [housetops?] or in the street along which the canephorus passes'

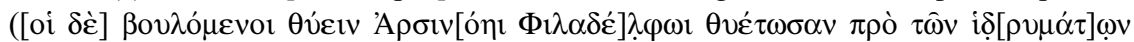

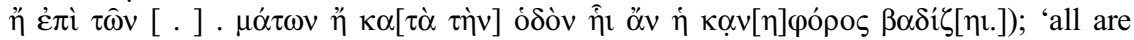
to build altars of sand. But if any have ready-built altars of brick, they are to strew

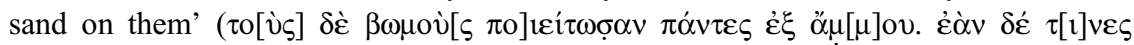

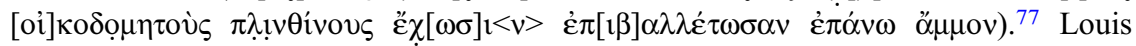
Robert brilliantly associated this decree with a series of stone plaques, most of which

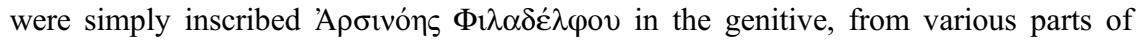
the Greek world. These plaques, he suggested, once formed part of the household altars referred to in the decree, which allowed private households to offer sacrifice to the queen. ${ }^{78}$

The cases of the Seleucids and the Ptolemies attest not only to the role of the royal house behind the seemingly spontaneous dedications but also to the use of house altars as a means of private participation in the public cults of rulers. As far as the Attalids are concerned, scholars generally agree that there is little or no evidence of a dynastic cult, ${ }^{79}$ but the strikingly similar series of altars and statue bases for Attalus I Sōtēr and Eumenēs II Sōtēr, and their concentration in the state capital, may point to some royal decree proclaiming the kings' epithet as official and requiring their worship with altars and sacrifice under that title. Some state organization was probably involved, though how precisely it was regulated-as, for instance, by some royal decree, which has not survived-can only be speculated upon.

Are we to suppose, then, that the dedications to Philip Sōter follow a similar pattern, namely that they were also prescribed by a public command? Compared to the striking series of dedications to the Attalids, however, only one is attested for Philip II Sōterr, whereas those for Philip V Sōtēr are attested in an isolated matter and scattered in different locations, and, as we have seen, not all of them can be securely shown to

76 J. Ma, 'Relire les Institutions des Séleucides de Bikerman', in S. Benoist (ed.), Rome, A City and its Empire in Perspective (Leiden, 2012), 59-84, at 79-81; J. Ma, 'Re-examining Hanukkah', Marginalia (2013), http://marginalia.lareviewofbooks.org/re-examining-hanukkah/. Private participation in a public cult by means of domestic sacrifice is prescribed also in OGIS 219, with L. Robert, 'Sur un decret d'Ilion et sur un papyrus concernant des cultes royaux', in Essays in Honor of C. Bradford Welles (New Haven, 1966), 175-211; SEG XLI 1003.1-26; I.Magnesia 100 (in n. 72).

77 P.Oxy. 2465 fr. 2, col. I (trans. P.Oxy.).

78 Robert (n. 76), esp. 192-4 (on the decree), 202-4 (on archaeological evidence). On dedications

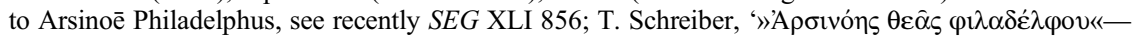
ein Miniaturaltar der Arsinoë II. im archäologischen Museum der westfälischen Wilhelms-Universität Münster', Boreas 34 (2011), 187-201 (SEG LXI 1538). Also related to the cult of Arsinoē might have been a series of crudely made Ptolemaic oinochoai decorated with relief showing a female figure pouring libation beside an altar: these might have been used by private households for libations when celebrating the cult. See D.B. Thompson, Ptolemaic Oinochoai and Portraits in Faience (Oxford, 1973), esp. 71-5, 117-22.

79 On the cults of the Attalids, see e.g. Hansen (n. 66), 453-70; D. Fishwick, The Imperial Cult in the Latin West (Leiden, 1987-), I.1, 17-18; cf. Allen (n. 66), 145-58, who thinks that a royal cult was probably founded in the year 188 when the Attalid kingdom expanded in power and territory following the treaty of Apamea. 
be altars. The piecemeal state of the evidence makes it much more difficult to determine if they were set up on an ad hoc basis as expressions of loyalty, allegiance or private devotion to Philip, or whether they were prescribed by some civic decree in relation to a public cult. We do not know, and perhaps need not suppose, that all the dedications for Philip fulfilled the same function and arose from one single context.

\section{CONCLUSION}

As with dedications to the gods, the possible reasons for dedicating to kings were many. Although much remains uncertain about the reasons and the contexts in which these objects were set up, they remind us, significantly, of the possible role of individuals in ruler cults: far from being a matter between the king and the civic community, ruler worship might also involve the participation of anonymous individuals whose role can easily elude us. Given the isolated nature of these dedications and the absence of corroborating evidence, however, we do not know whether the dedications to Philip II Sōtēr and Philip V Sōtēr concern a private or a public cult, that is, whether individuals were honouring the king on their own initiative, or whether they were participating in a public cult in accordance with some civic or royal decree (as may be the case suggested for the Attalids). Individuals' cult practices and use of royal epithets are likely to have followed civic practices. Nevertheless, we cannot rule out the possibility that in some cases private practices might operate independently of, or even affect, public ones. ${ }^{80}$ Public and private worship of monarchs could therefore influence, reinforce and interact with each other.

The dedications from Maroneia, Thasos and elsewhere not only raise questions of private participation in ruler cults but also challenge us to reassess some of the widely held assumptions about the Macedonian kings, who are often thought to be less prominent in receiving cult than their Ptolemaic, Seleucid and Attalid counterparts. Long ago it was assumed that Antigonus II Gonatas did not receive cult, but subsequently one instance in Rhamnus and possibly another in Ios have come to light. ${ }^{81}$ If the various dedications in Maroneia, Nikiti and the second one from Thasos are correctly identified as belonging to Philip V, it would be another example of a Hellenistic king called Sōtēr, and another instance where modern preconceptions about a Macedonian king's divinity (or the lack thereof) need to be reconsidered.

Lancaster University

THEODORA SUK FONG JIM

t.jim@lancaster.ac.uk

\footnotetext{
${ }^{80}$ See e.g. OGIS 19 and O. Rubensohn, 'Neue Inschriften aus Ägypten', Archiv für Papyrusforschung und verwandte Gebiete 5 (1909), 156-8 no. 1, both of which are dedications set up by individuals in honour of (accusative) Ptolemy I Sōtēr during his lifetime. That Ptolemy I is called Sōtēr in these two lifetime dedications is significant, as other epigraphic attestations of his title all date to the period after his death. It seems possible that some individuals were already calling him Sōtēr independently of, and prior to, the official adoption and promotion of that cult title by the Ptolemaic royal house, which happened only after his death during the reign of his son Ptolemy II. I will discuss this phenomenon in greater detail in a later study.

${ }^{81}$ Petrakos (n. 59), no. 7 (262-240/239 в.C.) $=S E G$ XLI 75 (before 236/235 B.c.); IG XII Supp. 168. Discussed in Habicht (n. 17), 65-73, 81, 256-7; C. Habicht, 'Divine honours of Antigonus Gonatas in Athens', SCI 15 (1996), 131-4 (reprinted in C. Habicht, The Hellenistic Monarchies [Ann Arbor, 2006], ch. 18).
} 